\title{
Production of hybrid strains among Pleutorus and Lentinula and evaluation of their mycelial growth kinetics on malt extract agar and wheat grain using the Gompertz and Hill models
}

\author{
Juan Diego Valenzuela Cobos ${ }^{1}$, Enrique Durán Páramo', Ramón Villanueva Arce', \\ María Eugenia Garín Aguilar², Abraham Sánchez Hernández ${ }^{1}$, Hermilo Leal Lara ${ }^{3}$, \\ Gustavo Valencia del Toro ${ }^{1 *}$

\begin{abstract}
${ }^{1}$ Laboratorio de Cultivos Celulares de la Sección de Estudios de Posgrado e Investigación. UPIBI, Instituto Politécnico Nacional. Barrio la Laguna s/n Ticomán. Ciudad de México CP 07340, México, ${ }^{2}$ Laboratorio de Farmacobiología de la Facultad de Estudios Superiores Iztacala, Universidad Nacional Autónoma de México. Av de los Barrios No.1. Los Reyes Iztacala, Tlalnepantla CP 54090. Edo. de México, México. ${ }^{3}$ Departamento de Alimentos y Biotecnología, Facultad de Química, Universidad Nacional Autónoma de México, Cd. Universitaria, 04510 Mexico D.F
\end{abstract}

\section{A B S T R A C T}

Three inter-generic hybrid strains were obtained by pairing compatible neohaplonts recovered by dedikaryotization of four parental strains, i.e. Pleurotus ostreatus (CC060), Pleurotus djamor (CC051) and Lentinula edodes (CC003 and CC004). Fifteen neohaplonts were recovered employing homogenization time periods for Pleurotus spp. since 60 to $90 \mathrm{~s}$, and for Lentinula edodes strains time periods ranged from 5 to $20 \mathrm{~s}$, and incubation at $28{ }^{\circ} \mathrm{C}$ in a peptone-glucose solution (PGS). The mycelial growth of the parental and hybrid strains was determined on malt extract agar (MEA) and wheat grain by calculating the parameters $A, B$ and $C$ of nonlinear regression models. For the parameter $A$, the mycelial growth on MEA showed values ranged from 1.08 to 1.28 , and for the parameter $B$ since 5.65 to 20.85 . On the other hand, the $A$ values by mycelium growth on wheat grain ranged from 1.57 to 16.13 , for $B$ since 28.36 to 86.53 and for $C$ were in an interval from 11.89 to 44.24 . Parental and hybrid strains presented instantaneous velocity values on MEA since 2.88 to 7.26 $\mathrm{cm}^{2} \bullet$ day ${ }^{-1}$, whereas on wheat grain were in an interval from 5.45 to $10.05 \mathrm{~cm}^{3} \bullet$ day ${ }^{-1}$. Furthemore, the $\mu_{\max }$ values on MEA and wheat grain were calculated by using the Gompertz model and the $\lambda$ values on both medium were estimated by using the Hill model, the $\mu_{\max }$ values on MEA ranged from 0.26 to 1.69 day $^{-1}$ and $\lambda$ values in an interval from 0.41 to 2.74 , whereas the $\mu_{\max }$ values on wheat grain ranged from 0.05 to $0.43 \mathrm{day}^{-1}$ and $\lambda$ since 1.82 to $28 \mathrm{~h}$. Moreover, the estimated equations based on nonlinear models were used to calculate the $\mu_{\max }$ values on MEA and wheat grain of the strains and the $\lambda$ values were obtained by using the $\mu_{\max }$ values of the proposed equations on the Hill model, the $\mu_{\max }$ values on MEA ranged from 0.44 to 1.27 day $^{-1}$ andthe $\lambda$ values between 0.57 to $1.72 \mathrm{~h}$, while the $\mu_{\max }$ values on wheat grain ranged from 0.04 to 0.64 day $^{-1}$ and $\lambda$ values in an interval from 1.26 to $20.11 \mathrm{~h}$. The results evidenced that the hybrid strains of PleurotusxLentinula presented highest rate of growth in comparison with the parental, encouraging the production of hybrid strain and their use in the industrial field.

Keywords: Dedikaryotization; Mycelium growth; Mushroom; Neohaplonts; Strains

\section{INTRODUCTION}

The production of new edible mushroom strains is restricted due to incompatibility barrier, in some cases hybrid strains are produced through mating compatible neohaplonts recovered by chemical dedikaryotization. This process allows the recovery of the two monokaryotic components from a dikaryon (LealLara and Eger-Hummel, 1982) by using toxic substances such as sodium taurocholate, colic acid, peptone or glucose (Miles and Raper, 1956).

The mushrooms with more production in the world are: 1) Agaricus (30\%); 2) Pleurotus spp. (27\%); Lentinula edodes

\footnotetext{
*Corresponding author:

Gustavo Valencia del Toro, Laboratorio de Cultivos Celulares de la Sección de Estudios de Posgrado e Investigación. UPIBI, Instituto Politécnico Nacional. Barrio la Laguna s/n Ticomán. Ciudad de México CP 07340, México.

E-mail: gvovaltor@yahoo.com.mx
} 
(17\%); Auricularia (6\%) and Flamulina (5\%) (Royse, 2014). In Mexico the mushrooms with highest production and demand are Agaricus bisporus, Pleurotus spp. and Lentinula edodes (Ramírez-Carrillo, 2011); in 2011 the annual production of Pleurotus spp. was 3000 tons and of Lentinula edodes was 25 tons; both species represented the $4.90 \%$ of total edible fungi production (Martínez-Carrera et al., 2012).

Pleurotus spp. and Lentinula edodes are characterized for their high nutritional value (Manzi et al., 2001; Reis et al., 2012; Zengin et al., 2015) and can be taken as an important source of proteins, vitamins and minerals (Manzi et al., 1999). However, in mushrooms the different species needs different conditions to grow and produce fruit body; Pleurotus spp. requires tropical and subtropical climates (Mori et al., 1974; Fultz, 1988; Kashangura et al., 2006), while Lentinula edodes needs long incubation times, specific substrates to produce fruits body and low temperature (Imbernon et al., 1983; Gaitán-Hernández et al., 2006; Sánchez-Hernández et al., 2014; Sharma et al., 2015).

The presented study aimed to obtain new strains of the genera PleurotusxLentinula; and evaluate the mycelium growth kinetics on malt extract agar and wheat grain in comparison with the parental strains.

\section{MATERIALS AND METHODS}

\section{Biological material}

In this research was used the following mushroom strains: two parental strains i.e. Pleurotus ostreatus (CC060) and Pleurotus djamor (CC051); two parental strains of Lentinula edodes CC003 (supplied from Faculty of Chemistry, UNAM) and CC004 (commercial strain); three hybrid strains $\mathrm{PO}_{2} \mathrm{xLC}_{2}, \mathrm{PO}_{5} \mathrm{xLC}, \mathrm{PD}_{4} \mathrm{xLC}_{3}$ obtained by mating compatible neohaplonts recovered by dedikaryotization of parental strains. Stocks of all strains are deposited at the fungal collection of the Cellular Cultures of the Biotechnology Interdisciplinary Professional Unit (UPIBI-IPN).

\section{Culture media}

The malt extract agar (MEA) was prepared by dissolving $18 \mathrm{~g}$ of malt extract and $15 \mathrm{~g}$ of bacteriological agar in $1 \mathrm{~L}$ of distilled water using an Erlenmeyer flask. The flask was sterilized in autoclave at $15 \mathrm{psi}\left(121^{\circ} \mathrm{C}\right)$ for $15 \mathrm{~min}$, subsequent, $10 \mathrm{~mL}$ of sterile medium were poured into sterile Petri dishes. The dishes with the medium solidified were wrapped in plastic bags and incubated at $28{ }^{\circ} \mathrm{C}$ for $24 \mathrm{~h}$ to check the sterility. Then, the Petri dishes without contamination were used for propagation of mycelium and storage of strains (Eger et al., 1976).

\section{Dedikaryotization solution (Peptone-Glucose Solution PGS)}

The dedikaryotization solution was prepared by dissolving in $1 \mathrm{~L}$ of distilled water with $20 \%$ of anhydrous glucose and $20 \%$ of peptone $\mathrm{P}$ (Oxoid LP0037). Thereafter, $50 \mathrm{~mL}$ were poured into glass jars and sterilized at $15 \mathrm{psi}\left(121^{\circ} \mathrm{C}\right)$ for $15 \mathrm{~min}$. Then, the glass jars with the dedikaryotization solution were incubated at $28{ }^{\circ} \mathrm{C}$ for $24 \mathrm{~h}$ to check the sterility (Leal-Lara and Eger-Hummel, 1982).

\section{Recovery of neohaplonts by dedikaryotization}

The mycelium in the Petri dish were divided in fourth parts and were put in a Blender (Model N.4237, Mark: Marnie) and were homogenized with $50 \mathrm{~mL}$ of sterile water. Different periods of time were used depending of the genera, by Pleurotus spp. strains were employed blending times of 60 and $90 \mathrm{~s}$, and for Lentinula edodes strains were blended with times of 5 and $20 \mathrm{~s}$. Then, the jars contained $50 \mathrm{~mL}$ of PGS were inoculated with 50 and $100 \mu \mathrm{L}$ of the homogenized inoculum, and incubated at $28^{\circ} \mathrm{C}$ until mycelium growth was noticeable. Thereafter, the liquid was homogenized with $50 \mathrm{~mL}$ of sterile distilled water for $20 \mathrm{~s}$ to both strain types. Subsequently MEA plates were inoculated with 15 and $20 \mu \mathrm{L}$ of the homogenized and incubated at $28{ }^{\circ} \mathrm{C}$ until colonies were formed. After that, the Petri dishes were observed under the microscope $10(\mathrm{x})$ to identify the micelyum without clamp connections (neohaplonts). Finally the monokaryotic components were cultivated individually on Petri dishes with $10 \mathrm{~mL}$ of MEA to verify under the microscope 10(x) the absence of clamp connections (Guadarrama-Mendoza et al., 2014).

\section{Identification of two types of neohaplonts (compatibility types)}

To identify the two types of neohaplonts for each parental strain, was necessary paired all the monokaryotic components of the same strain among them on MEA dishes. Subsequently the Petri dishes were incubated at $28{ }^{\circ} \mathrm{C}$ and inspected under the microscope 10 (x) every day to determine the mycelium with presence of clamp connections. Then the dikaryon was cultivated on MEA plates to verify presence of clamp connections (Valencia del Toro and Leal-Lara, 1999; Valencia del Toro and Leal-Lara, 2002).

\section{Production of hybrid strains of Pleurotusx Lentinula by pairing compatible neohaplonts}

The neohaplonts obtained from the Pleurotus spp. were paired with the monokaryotic components of Lentinula edodes on Petri dishes using $10 \mathrm{~mL}$ of MEA in all possible combinations. Then, the plates were incubated at $28{ }^{\circ} \mathrm{C}$ and inspected under the microscope $10(\mathrm{x})$ each $24 \mathrm{~h}$ to determine the strain with presence of clamp connections. Finally to check presence of clamp connections the new strain was cultivated on MEA plates (Valencia del Toro and Leal-Lara, 2002). 


\section{Mycelial growth kinetics on MEA with no linear model} The mycelial growth rate on Petri dish with MEA was estimated by the diameter of the colony, and the growth velocity was determinate used the following nonlinear regression model (Regina, 2001):

$\mathrm{f}^{\prime}(\mathrm{x})=\mathrm{B}^{*} \mathrm{~A}^{\mathrm{x} *} \ln (\mathrm{A})$, where:

$\mathrm{A}, \mathrm{B}=$ parameters of the model

$\mathrm{x}=$ days

$\mathrm{f}^{\prime}(\mathrm{x})=$ growth velocity

Based on this math model was predictable the next equation to determinate the maximum growth $\left(\mu_{\max }\right)$ on MEA and the lag time $(\lambda)$ was calculated by using the $\mu_{\max }$ value on the Hill model.

$\mu_{\max }=M /(A * B)$, where: $M=$ day with maximum growth rate $\lambda=\left[\ln \left(1+\left(\mu_{\max } / \mathrm{v}\right)\right] / \mu_{\max }\right.$, where: $\mathrm{v}=\mu_{\max }$

\section{Mycelial growth kinetics on grain wheat with no linear model}

Mycelial growth was evaluated daily by measurement the diameter of the colony when filled the bag with wheat grain, and the velocity was calculated by using with the next nonlinear regression model (Regina, 2001):

$\mathrm{f}^{\prime}(\mathrm{x})=-[(2 \mathrm{~A}+\mathrm{C}) * \mathrm{~B}] /(\mathrm{x}+\mathrm{A}) *(-\mathrm{A}-\mathrm{C}+\mathrm{x})$, where:

$\mathrm{A}, \mathrm{B}, \mathrm{C}=$ parameters of the model

$\mathrm{x}=$ days

$\mathrm{f}^{\prime}(\mathrm{x})=$ growth velocity

To determinate the $\mu_{\max }$ values of the strains on wheat grain based on this nonlinear model was proposed the following formula and the lag phase $(\lambda)$ was calculated by using the $\mu_{\max }$ value on the Hill model.

$\mu_{\max }=M /(A * C)$, where: $M=$ day with maximum growth rate $\lambda=\left[\ln \left(1+\left(\mu_{\max } / \mathrm{v}\right)\right] / \mu_{\max }\right.$, where: $\mathrm{v}=\mu_{\max }$

\section{Mycelial growth kinetics with Gompertz model}

The modified Gompertz model consists of three phases: lag, exponential, and stationary phases and was used to determinate the kinetics of mycelium growth on MEA and wheat grain (Gibson et al., 1987; Liu et al., 2017):

$\log \mathrm{N}=\mathrm{A}+\mathrm{C}^{*} \exp \{-\exp [-\mathrm{B}(\mathrm{t}-\mathrm{M})]\}$, where:

A, B, C $=$ parameters of the model $\mathrm{t}=$ days of mycelial colonization

$\mathrm{M}=$ day with maximum growth rate

$\log \mathrm{N}=$ growth kinetics
By using the parameters of the model was calculated the maximum growth $\left(\mu_{\max }\right)$ and the lag time $(\lambda)$ (Gibson et al., 1987; Hills and Wright, 1994):

$\mu_{\max }=\left(\mathrm{B}^{*} \mathrm{C}\right) / \mathrm{e}$, where: $\mathrm{e}=$ The Euler constant

$\lambda=\left[\ln \left(1+\left(\mu_{\max } / \mathrm{v}\right)\right] / \mu_{\max }\right.$, where: $\mathrm{v}=\mu_{\max }$

\section{Statistical analysis}

The results were examined using one-way analysis of variance (ANOVA) to determine the significance of individual differences at $\mathrm{p}<0.05$ level, of $\mathrm{A}, \mathrm{B}$ or $\mathrm{C}$ parameters of the models and for comparing the velocity growth in different days of growth, the maximum growth specific speed $\left(\mu_{\max }\right)$ and the lag phase $(\lambda)$, when statistical differences were found, the Duncan Test with $\alpha=0.05$ was applied. Also the analysis of variance of measure repeated was used to compare the behavior of each strain in the time. The $\chi^{2}$ test was applied to determinate the symmetry in the recovery of neohaplonts of parental strain. The analyses were carried out using Statgraphic ver. 16 statistical software.

\section{RESULTS AND DISCUSSION}

\section{Chemical dedikaryotization}

Parental strains were dedikariotized and fifteen monokaryotic components were recovered by using different conditions such as: time of blending between 60 to $90 \mathrm{~s}$ for Pleurotus and for Lentinula edodes times of blending ranged from 5 to $20 \mathrm{~s}$, and volume of inoculation in in the dedikaryotization solution between 50 to $100 \mu \mathrm{L}$ and volume of inoculation on MEA since 15 to $20 \mu \mathrm{L}$ (Table 1).

Valencia del Toro and Leal-Lara (1999) used homogenization times $150 \mathrm{~s}$ and incubation time from 48 to $120 \mathrm{~h}$ in the dedikaryotization solution to recover 32 monokaryotic components of three Pleurotus spp., whereas Guadarrama-Mendoza et al. (2014) proved blending times among 40 and $70 \mathrm{~s}$ and incubation time of $72 \mathrm{~h}$ in peptoneglucose solution (PGS) to recover 15 neohaplonts of two Pleurotus spp.

On the other hand, Ramírez-Carrillo and Leal-Lara (2002) used homogenization time from 5 to $150 \mathrm{~s}$ and incubation time of $72 \mathrm{~h}$ in the dedikaryotization solution (PGS) to recover 23 monokaryons of seven Lentinula edodes strains.

The authors presented symmetrical recovery of neohaplonts, include the CCOO3 strain studied by Ramírez-Carrillo and Leal-Lara (2002) but needed volume of inoculum of $50 \mu \mathrm{L}$ in petri dishes with MEA.

The reduced number of neohaplonts obtained and the symmetric recover is directly related with the mechanic 
Table 1: Conditions to recover monokaryotic components of the parental strains by chemical dedikaryotization process

\begin{tabular}{|c|c|c|c|c|c|c|c|}
\hline \multirow[t]{2}{*}{ Strains } & \multirow[t]{2}{*}{ Time of blending (s) } & \multicolumn{2}{|c|}{ Volume of inoculum $(\mu \mathrm{L})$} & \multicolumn{3}{|c|}{ Neohaplonts } & \multirow{2}{*}{$\begin{array}{l}\chi^{2} \text { test for symmetric } \\
\text { recovery }(\mathrm{nh} 1: \mathrm{nh} 2=1: 1)^{\text {* }}\end{array}$} \\
\hline & & $\begin{array}{c}\text { Dedikaryotization } \\
\text { solution }\end{array}$ & Malt extract agar & Total & Type nh1 & Type nh2 & \\
\hline \multirow[t]{4}{*}{$\mathrm{CC060}$} & 60 & 50 & 15 & 1 & 3 & 2 & $0.20(0.66)$ \\
\hline & 60 & 50 & 20 & 1 & & & \\
\hline & 60 & 100 & 20 & 2 & & & \\
\hline & 90 & 50 & 20 & 1 & & & \\
\hline \multirow[t]{4}{*}{ CC051 } & 60 & 50 & 15 & 1 & 4 & 1 & $1.8(0.18)$ \\
\hline & 60 & 50 & 20 & 1 & & & \\
\hline & 90 & 50 & 15 & 1 & & & \\
\hline & 90 & 100 & 15 & 2 & & & \\
\hline $\mathrm{CCO03}$ & 5 & 50 & 20 & 2 & 2 & 0 & - \\
\hline \multirow[t]{2}{*}{$\mathrm{CCOO4}$} & 5 & 50 & 15 & 1 & 2 & 1 & $0.33(0.56)$ \\
\hline & 20 & 50 & 15 & 2 & & & \\
\hline
\end{tabular}

${ }^{*}$ Test reference value $\chi^{2}(p<0.05)$. Smaller $\chi^{2}$ values indicate no significant differences

sensitivity of the strains, volume of inoculum, blending times and incubation time used (Kawasumi et al., 1987; Ramírez-Carrillo and Leal-Lara, 2002) in comparison with the authors. Moreover, the neohaplonts presented symmetrical recovery to difference of the CC003 strain that only was possible to get one type, because were used volume of inoculum between $15-20 \mu \mathrm{L}$ in petri dishes with MEA.

\section{Formation of inter-generic strains}

The neohaplonts recovered from the four parental strains formed 3 hybrid strains by mating of 10 Pleurotus neohaplonts with 5 monokaryons of Lentinula edodes. Table 2 shows the pairing of neohaplonts to formation of inter-generic hybrid. Some authors have published about formation of inter-generic hybrid with consistent results, Ramírez-Carrillo et al. (2011) reported the formation of 11 hybrid inter-generic strains through pairing 11 neohaplonts of Pleurotus eryngii with 6 monokaryons of Lentinula edodes, whereas Sánchez-Hernández et al. (2014) produced 12 inter-generic hybrid by mating 6 neohaplonts of Lentinula edodes with 2 monokaryotic components of Pleurotus ostreatus.

Production protoplast is other way to the formation of inter-generic strains, Chakraborty and Sikdar (2008) presented the formation of 12 somatic hybrids between Volvariella volvacea and Pleurotus florida through intergeneric protoplast fusion, while Mallik and Sikdar (2014) presented 9 inter-generic strains produced of through protoplast fusion between Pleurotus florida and Lentinula edodes.

To pair monokaryons of different strains is necessary break down the compatibility barrier of the species; only in that moment will be possible obtain hybrid stains with characteristic of the parental strains (Eichlerová and Homolka, 1999; Eichlerová et al., 2000).
Table 2: Formation of hybrid strains by mating compatible neohaplonts inter-generic

\begin{tabular}{|c|c|c|c|c|c|c|}
\hline \multicolumn{7}{|c|}{$\begin{array}{l}\text { Formation of hybrid strains by mating compatible } \\
\text { neohaplonts inter-generic }\end{array}$} \\
\hline \multicolumn{2}{|r|}{ Strains } & \multicolumn{2}{|c|}{$\mathrm{CCO03}$} & \multicolumn{3}{|c|}{$\mathrm{CCOO4}$} \\
\hline Strains & Neohaplonts & 1 & 2 & 1 & 2 & 3 \\
\hline CC060 & 1 & - & - & - & - & - \\
\hline 2 & - & - & - & + & - & \\
\hline 3 & - & - & - & - & - & \\
\hline 4 & - & - & - & - & - & \\
\hline 5 & - & - & - & + & - & \\
\hline CC051 & 1 & - & - & - & - & - \\
\hline 2 & - & - & - & - & - & \\
\hline 3 & - & - & - & - & - & \\
\hline 4 & - & - & - & - & $\overline{-}$ & \\
\hline \multirow{2}{*}{5} & - & - & - & - & + & \\
\hline & - & - & - & - & - & \\
\hline+ & Positive pairing=dikary & & & & & \\
\hline- & Negative pairing=incom & tibili & eoha & & & \\
\hline
\end{tabular}

\section{Mycelial growth speed of parental and hybrid strains on MEA and wheat grain}

The instantaneous velocities of parental and hybrid strains on MEA were compared showing speed values ranged from 3.44 to $6.45 \mathrm{~cm}^{2} \bullet$ day $^{-1}$ for parental strains, whereas the hybrid strains presented velocity values since 2.88 to $7.26 \mathrm{~cm}^{2} \bullet$ day ${ }^{-1}$ on the $9^{\text {th }}$ day. Similarly results have been presented by Regina (2001), this author evaluated growth rate for two strains of Lentinula edodes in different culture media showing instantaneous velocity values since 3.69 to $10.70 \mathrm{~cm}^{2} \bullet$ day ${ }^{-1}$ on the $10^{\text {th }}$ day, while Castro et al. (2006) introduced growth rate for four strains of Lentinula edodes under different agar medium compositions showing instantaneous speed values since 6.0 to $8.5 \mathrm{~cm}^{2} \bullet$ day $^{-1}$ on the $9^{\text {th }}$ day. The different values of instantaneous velocity with these authors depend of the different culture media used to the mycelium growth.

Figure 1 shows the increasing growth speed on MEA, due to the rich content of nutrients in the culture media, Straatsma et al. (1991) indicates that nutritive medium 


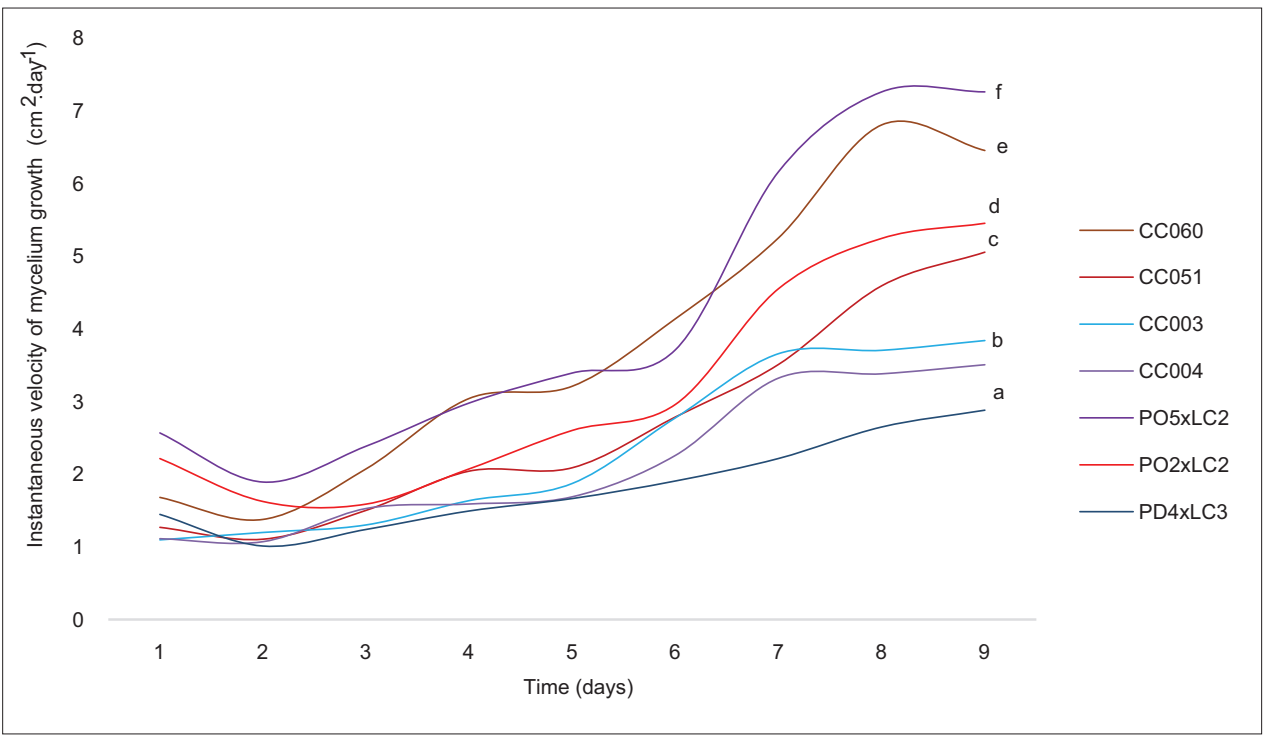

Fig 1. Mycelium growth curves of the parental and hybrid strains on MEA. Different letters indicated significant difference among of the instantaneous velocity values of the dikaryotic strains at level $p<0.05$, according to Duncan test, $n=10$.

promotes the vigor of the mycelium. According to the Duncan test the hybrid strain $\mathrm{PO}_{5} \mathrm{xLC}$ presented the highest instantaneous speed $7.26 \mathrm{~cm}^{2} \cdot$ day $^{-1}$ on MEA even better than the parent strains (CC060 and CC004), the first one showed the second one highest speed $6.45 \mathrm{~cm}^{2} \bullet$ day ${ }^{-1}$, while the second presented a low speed $3.44 \mathrm{~cm}^{2} \bullet$ day ${ }^{-1}$, these results suggest that the hybrid showed a metabolic capacity and growth rate closer to Pleurotus spp.

The mycelial growth rate on MEA was determined according to the nonlinear model, which allows determinate the parameters A and B from the growth velocity of the strains on area $\left(\mathrm{cm}^{2} \bullet \mathrm{day}^{-1}\right)$. The $\mathrm{A}$ values for the parental and hybrid strains ranged from 1.08 to 1.28 and $B$ values in an interval from 5.65 to 20.85 . These results are similar to some authors, Regina (2001) measured the mycelial growth for two strains of Lentinula edodes in different culture media showing A values since 1.09 to 1.29 and $\mathrm{B}$ values ranged from 3.58 to 38.04 .

$\mathrm{A}$ is the parameter that indicates the maximum potential of the growth rate, while $B$ is the biological variable that related the growth speed and the incubation time (Fekedulegn et al., 1999). Table 3 shows that hybrid $\mathrm{PO}_{5} \mathrm{xLC}_{2}$ presents the highest $A$ values in comparison with the other strains, and this confirm the previous results that this hybrid submitted the highest speed.

Instantaneous velocities of dikaryotic strains on wheat grain were compared showing instantaneous velocity values since 5.45 to $7.53 \mathrm{~cm}^{3} \bullet$ day $^{-1}$ for parental strains, whereas the hybrid strains presented speed values were in an interval from 8.70 to $10.05 \mathrm{~cm}^{3} \cdot$ day $^{-1}$ on the $9^{\text {th }}$ day. Regina (2001) reported growth rate for two strains of Lentinula edodes in different substrates showing instantaneous speed values since 0.24 to $0.32 \mathrm{~cm}^{3} \cdot$ day $^{-1}$ on the $10^{\text {th }}$ day.

Figure 2 shows the decreasing growth speed on wheat grain, which is probably induced by the low aeration of the substrate (Leatham and Stahmann, 1987; Edwards, 1993) indicated that the low gas exchange is an inhibitory factor and causes that big part of ATP is used in other processes different to the mycelium growth. Multiple range test indicated that the hybrid strain $\mathrm{PO}_{2} \mathrm{xLC}_{2}$ presented the highest instantaneous speed $10.05 \mathrm{~cm}^{3} \bullet$ day $^{-1}$ on wheat grain even than the parental (CCO60 and CC004),

The first strain showed a speed $6.37 \mathrm{~cm}^{3} \bullet$ day $^{-1}$, while the second presented the lowest speed $5.62 \mathrm{~cm}^{3}$ day $^{-1}$, so this is possible to infer that $\mathrm{PO}_{2} \mathrm{xLC}_{2}$ can absorb of a better way the nutrients of the medium and growth rate closer to Pleurotus spp.

The determination of mycelial growth rate on wheat grain was calculated by using a nonlinear regression model, that permits determinate the parameters $\mathrm{A}, \mathrm{B}$ and $\mathrm{C}$ from the mycelial growth speed on volume $\left(\mathrm{cm}^{3} \bullet \mathrm{day}^{-1}\right)$. The A values estimated ranged from 1.57 to 16.13 , for $\mathrm{B}$ since 28.36 to 86.53 and for $C$ values in an interval from 11.89 to 44.24. Regina (2001) calculated the mycelial speed on different substrates for two strains of Lentinula edodes reporting A values since 0.84 to 1.20 , B values ranged from 0.96 to 1.40 and for $\mathrm{C}$ values in an interval from 18.1 to 27.9.

$B$ is the variable that indicate the maximum growth rate of the strain in correlation with $\mathrm{A}$, whereas $\mathrm{C}$ is the biological constant that correlated the incubation time and the instantaneous velocity (Fekedulegn et al., 1999). Table 4 


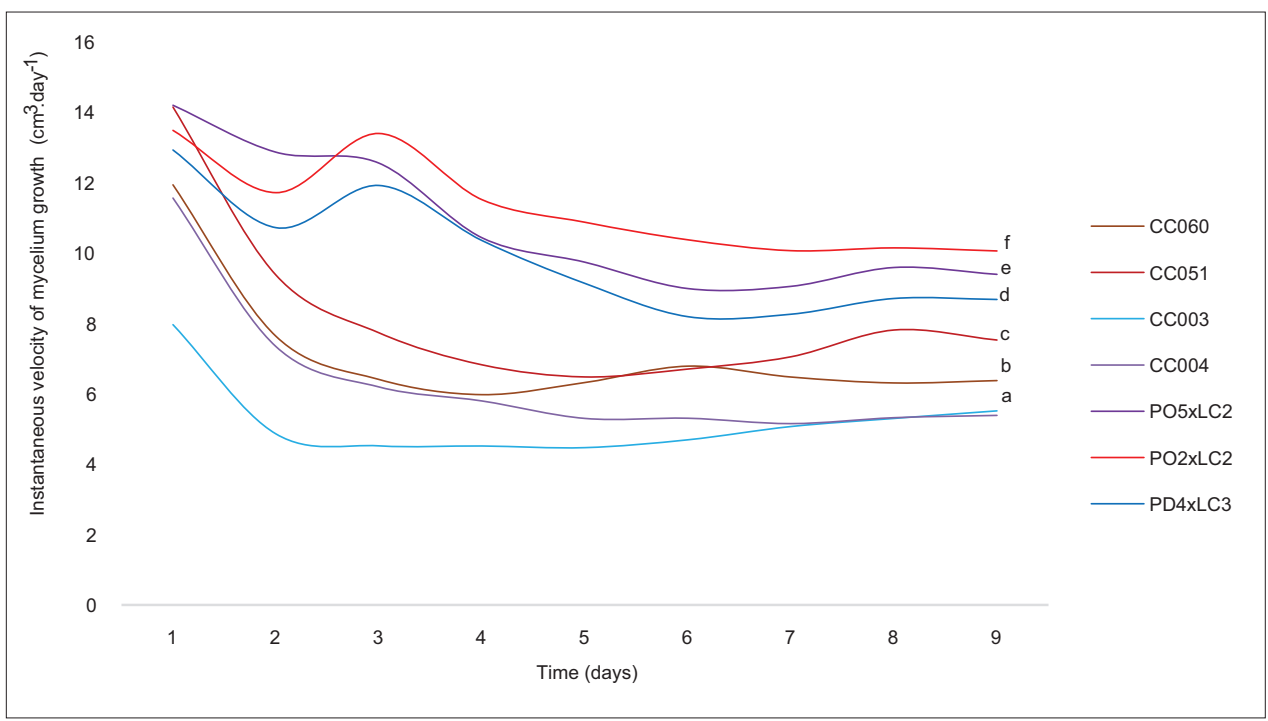

Fig 2. Mycelium growth curves of the parental and hybrid strains on wheat grain. Different letters indicated significant difference among of the instantaneous speed values of the dikaryotic strains at level $p<0.05$, according to Duncan test, $n=10$.

Table 3: Comparation of the parameters $A$ and $B$ used in the determination of mycelial growth on MEA of parental and hybrid strains

\begin{tabular}{lcc} 
Strains & $\mathbf{A}^{*}$ & $\mathbf{B}^{*}$ \\
\hline $\mathrm{CC} 060$ & $1.21 \pm 0.03^{\mathrm{e}}$ & $7.39 \pm 4.46^{\mathrm{a}}$ \\
$\mathrm{CC} 051$ & $1.21 \pm 0.04^{\mathrm{e}}$ & $7.15 \pm 2.41^{\mathrm{a}}$ \\
$\mathrm{CC} 003$ & $1.11 \pm 0.09^{\mathrm{b}}$ & $19.59 \pm 6.38^{\mathrm{c}}$ \\
$\mathrm{CC} 004$ & $1.08 \pm 0.01^{\mathrm{a}}$ & $20.85 \pm 6.32^{\mathrm{c}}$ \\
$\mathrm{PO}_{2} \times \mathrm{LC}_{2}$ & $1.13 \pm 0.01^{\mathrm{c}}$ & $12.68 \pm 2.37^{\mathrm{b}}$ \\
$\mathrm{PO}_{5} \times \mathrm{LC}_{2}$ & $1.28 \pm 0.16^{\mathrm{f}}$ & $5.89 \pm 1.49^{\mathrm{a}}$ \\
$\mathrm{PD}_{4} \times \mathrm{LC}_{3}$ & $1.17 \pm 0.11^{\mathrm{d}}$ & $12.65 \pm 1.59^{\mathrm{b}}$ \\
\hline
\end{tabular}

${ }^{*}$ Different letters in each column indicated significant difference among the parameters values at level $\mathrm{P}<0.05$, according to Duncan test, $\mathrm{n}=10$

Table 4: Comparation of the parameters A, B and C used in the determination of mycelial growth on wheat grain for the parental and hybrid strains

\begin{tabular}{lccc}
\hline Strains & $\mathbf{A}^{*}$ & $\mathbf{B}^{*}$ & $\mathbf{C}^{*}$ \\
\hline $\mathrm{CC} 060$ & $3.38 \pm 2.20^{\mathrm{b}}$ & $33.93 \pm 5.59^{\mathrm{a}}$ & $15.85 \pm 1.47^{\mathrm{a}}$ \\
$\mathrm{CC} 051$ & $1.57 \pm 0.74^{\mathrm{a}}$ & $28.36 \pm 2.76^{\mathrm{a}}$ & $14.21 \pm 0.68^{\mathrm{a}}$ \\
$\mathrm{CC003}$ & $5.23 \pm 2.08^{\mathrm{c}}$ & $48.93 \pm 11.10^{\mathrm{b}}$ & $31.31 \pm 2.90^{\mathrm{c}}$ \\
$\mathrm{CC004}$ & $16.13 \pm 4.49^{\mathrm{e}}$ & $86.14 \pm 18.60^{\mathrm{d}}$ & $44.24 \pm 9.02^{\mathrm{d}}$ \\
$\mathrm{PO}_{2} \times \mathrm{LC}_{2}$ & $7.70 \pm 2.67^{\mathrm{d}}$ & $86.53 \pm 23.27^{\mathrm{e}}$ & $20.62 \pm 6.82^{\mathrm{b}}$ \\
$\mathrm{PO}_{5} \times \mathrm{LC}_{2}$ & $4.62 \pm 1.57^{\mathrm{c}}$ & $65.13 \pm 10.72^{\mathrm{c}}$ & $11.89 \pm 1.65^{\mathrm{a}}$ \\
$\mathrm{PD}_{4} \times \mathrm{LC}_{3}$ & $7.82 \pm 2.21^{\mathrm{d}}$ & $85.83 \pm 16.92^{\mathrm{d}}$ & $27.81 \pm 6.18^{\mathrm{c}}$ \\
\hline
\end{tabular}

*Different letters in each column indicated significant difference among the parameters values at level $\mathrm{P}<0.05$, according to Duncan test, $\mathrm{n}=10$

presents a statistical relation between the parameters $\mathrm{A}$ and $\mathrm{B}$, so confirm the results obtained that the hybrid $\mathrm{PO}_{2} \mathrm{xLC}_{2}$ submitted the highest instantaneous velocity.

\section{Mycelial growth kinetics of dikaryotic strains on MEA and wheat grain}

The Gompertz and Hill models describe the best growth tendencies both in terms of statistical accuracy and simplicity (McDonald and Sun, 1999) and their parameters
$\mathrm{A}, \mathrm{B}$ and $\mathrm{C}$ were used to determinate the maximum growth specific speed $\left(\mu_{\max }\right)($ Gil et al., 2011) and the lag time $(\lambda)$ (Hill and Wright, 1994) of the strains.

Dikaryotic strains showed $\mu_{\max }$ values on MEA by using the estimated equation based on the nonlinear regression model ranged from 0.44 to 1.27 day $^{-1}$ and with the modified Gompertz model since 0.26 to 1.69 day $^{-1}$. On the other hand, the strains showed $\mu_{\max }$ values on wheat grain with the proposed equation estimated by the nonlinear model between 0.04 to 0.64 day $^{-1}$ and with the Gompertz model ranged from 0.05 to $0.43 \mathrm{day}^{-1}$ (Table 5). López-Peña et al. (2013) obtained $\mu$ max values of 0.05 and 0.13 day $^{-1}$ for mycelial growth kinetics of three Lentinula edodes strains on liquid medium supplemented with vine wood extracts. For otherwise, Guillén-Navarro et al. (1998) reported $\mu_{\max }$ values for growth kinetics of Pleurotus ostreatus on agar DLA by calculating the value of the slope of 0.86 day $^{-1}$ on $12^{\text {th }}$ day, also presented $\mu_{\max }$ value of 0.65 day $^{-1}$ of the same strain on synthetic medium with yeast extract and glucose concentration of $2.5(\mathrm{~g} / \mathrm{L})$. The $\mu_{\max }$ indicates the better capacity of the strain to absorb the nutrients on both medium (Liu et al., 2017), the hybrid $\mathrm{PO}_{5} \mathrm{xLC}_{2}$ presented the highest instantaneous velocity values $\left(\mu_{\max }\right)$, therefore this strain can adapt easily on MEA and wheat grain even better than the parental strains.

All the strains presented $\lambda$ values on MEA by using the Gompertz model since 0.41 to 2.74 hand with the estimated formula based on a nonlinear model ranged from 0.57 to $1.72 \mathrm{day}^{-1}$. For otherwise, with the proposed equation the dikaryotic strains showed $\lambda$ values on wheat strain between 1.26 to $20.11 \mathrm{~h}$ and with the Gompertz model ranged from 1.82 to $28 \mathrm{~h}$ (Table 6). These results 
Valenzuela-Cobos, et al.: Models of mycelial growth kinetics

Table 5: Comparation of $\mu_{\text {max }}$ values of the dikaryotic strains on MEA and wheat grain

\begin{tabular}{|c|c|c|c|c|}
\hline \multirow[t]{2}{*}{ Strains } & $\begin{array}{c}\text { Gompertz } \\
\text { Model }\end{array}$ & $\begin{array}{c}\text { Nonlinear } \\
\text { Model }\end{array}$ & Gompertz Model & Nonlinear Model \\
\hline & $\begin{array}{c}\mu_{\max }(\text { MEA) } \\
(\text { day-1)* }\end{array}$ & $\begin{array}{c}\mu_{\max }(\text { MEA) } \\
(\text { day-1)* }\end{array}$ & $\mu_{\max }$ (wheat grain) (day-1)* & $\mu_{\max }$ (wheat grain) (day-1)* \\
\hline $\mathrm{CCO60}$ & $1.01 \pm 0.21^{d}$ & $1.18 \pm 0.37^{b}$ & $0.11 \pm 0.07^{b}$ & $0.34 \pm 0.18^{b}$ \\
\hline CC051 & $0.86 \pm 019^{c}$ & $1.12 \pm 0.32^{b}$ & $0.22 \pm 011^{c}$ & $0.61 \pm 0.19^{c}$ \\
\hline $\mathrm{CCOO3}$ & $0.32 \pm 0.05^{a}$ & $0.46 \pm 0.17^{a}$ & $0.23 \pm 0.20^{c}$ & $0.16 \pm 0.07^{a}$ \\
\hline $\mathrm{CCOO4}$ & $0.26 \pm 0.03^{a}$ & $0.44 \pm 0.16^{a}$ & $0.05 \pm 0.03^{a}$ & $0.04 \pm 0.02^{\mathrm{a}}$ \\
\hline $\mathrm{PO}_{2} \times \mathrm{LC}_{2}$ & $0.57 \pm 0.05^{b}$ & $0.64 \pm 0.10^{a}$ & $0.36 \pm 0.09^{e}$ & $0.09 \pm 0.06^{a}$ \\
\hline $\mathrm{PO}_{5} \times \mathrm{LC}_{2}$ & $1.69 \pm 0.23^{e}$ & $1.27 \pm 0.32^{b}$ & $0.43 \pm 0.13^{f}$ & $0.64 \pm 0.28^{c}$ \\
\hline $\mathrm{PD}_{4} \times \mathrm{LC}_{3}$ & $0.46 \pm 0.04^{b}$ & $0.61 \pm 0.06^{a}$ & $0.31 \pm 0.12^{d}$ & $0.07 \pm 0.03^{a}$ \\
\hline
\end{tabular}

Different letters in each column indicated significant difference among the $\mu_{\max }$ values on MEA and wheat grain of the parental and hybrid strains at level $P<0.05$, according to Duncan test, $n=10$

Table 6: Comparation of $\lambda$ values of the dikaryotic strains on MEA and wheat grain

\begin{tabular}{|c|c|c|c|c|}
\hline \multirow[t]{2}{*}{ Strains } & $\begin{array}{c}\text { Gompertz } \\
\text { Model }\end{array}$ & $\begin{array}{c}\text { Nonlinear } \\
\text { Model }\end{array}$ & Gompertz Model & Nonlinear Model \\
\hline & $\lambda\left(\right.$ MEA) (h) ${ }^{*}$ & $\lambda\left(\right.$ MEA) $(h)^{*}$ & $\lambda$ (wheat grain) $(\mathrm{h})^{\star}$ & $\lambda$ (wheat grain) (h) \\
\hline $\mathrm{CC} 060$ & $0.71 \pm 0.16^{b}$ & $0.68 \pm 0.37^{a}$ & $13.86 \pm 17.19^{b}$ & $2.52 \pm 1.32^{\mathrm{a}}$ \\
\hline $\mathrm{CC} 051$ & $0.84 \pm 0.21^{b}$ & $0.66 \pm 0.20^{\mathrm{a}}$ & $7.17 \pm 11.52^{\mathrm{a}}$ & $1.27 \pm 0.52^{\mathrm{a}}$ \\
\hline $\mathrm{CCOO3}$ & $2.22 \pm 0.32^{\mathrm{e}}$ & $1.68 \pm 0.55^{c}$ & $4.27 \pm 1.91^{\mathrm{a}}$ & $5.04 \pm 2.38^{b}$ \\
\hline $\mathrm{CCOO4}$ & $2.74 \pm 0.58^{f}$ & $1.72 \pm 0.51^{c}$ & $28.00 \pm 20.55^{c}$ & $20.11 \pm 7.36^{d}$ \\
\hline $\mathrm{PO}_{2} \times \mathrm{LC}_{2}$ & $1.22 \pm 0.12^{\mathrm{c}}$ & $1.10 \pm 0.19^{b}$ & $2.04 \pm 0.53^{\mathrm{a}}$ & $10.37 \pm 5.39^{c}$ \\
\hline $\mathrm{PO}_{5} \times \mathrm{LC}_{2}$ & $0.41 \pm 0.05^{\mathrm{a}}$ & $0.57 \pm 0.11^{\mathrm{a}}$ & $1.82 \pm 0.72^{\mathrm{a}}$ & $1.26 \pm 0.36^{\mathrm{a}}$ \\
\hline $\mathrm{PD}_{4} \times \mathrm{LC}_{3}$ & $1.52 \pm 0.16^{d}$ & $1.13 \pm 0.11^{\mathrm{b}}$ & $2.65 \pm 1.17^{a}$ & $10.90 \pm 4.38^{c}$ \\
\hline
\end{tabular}

Different letters in each column indicated significant difference among the $\lambda$ values on MEA and wheat grain of the parental and hybrid strains at level $P<0.05$, according to Duncan test, $\mathrm{n}=10$

are similar to other authors using different math models, Straatsma et al. (1991) reported $\lambda$ values for $A$. bisporus since 0.46 to $0.71 \mathrm{~h}$ by using logistic functions. The lag phase $(\lambda)$ indicates the capacity of the strain to adapt to new environmental condition (Chatterjee et al., 2015), in relation with this the hybrid $\mathrm{PO}_{5} \mathrm{xLC}_{2}$ presented the shorter lag time $(\lambda)$, hence this strain can get to the exponential phase faster to the other strains even to the parental strain.

\section{CONCLUSIONS}

The nonlinear regression models showed that the hybrid $\mathrm{PO}_{5} \mathrm{xLC}_{2}$ and $\mathrm{PO}_{2} \mathrm{xLC}_{2}$ presented the highest instantaneous velocity values on MEA and wheat grain, these results are according to the Gompertz and Hill models that confirmed that the hybrid $\mathrm{PO}_{5} \mathrm{xLC}_{2}$ presented the maximum growth specific speed $\left(\mu_{\max }\right)$ and shorter phase duration $(\lambda)$ on MEA and wheat grain.

The estimated equation calculated similar $\mu_{\max }$ values to the indicated by the modified Gompertz model, also can be used the values of the $\mu_{\max }$ to calculate the $\lambda$ by using the Hill model.

The results obtained of the mycelial growth rate of the new strains represent a positive predictor to increase the development of hybrid strains to raise the commercial production at industrial level.

\section{ACKNOWLEDGEMENTS}

Financial support received for: IPN-SIP Project: 20170419, CONACYT Project: CB-2016- 611914.

\section{REFERENCES}

Castro, M. R., P. J. Souza and A. F. Eira. 2006. Digital monitoring of mycelium growth kinetics and vigor of Shiitake (Lentinula edodes Berk. Pegler) on agar medium. Braz. J. Microbiol. 37: 90-95.

Chakraborty, U. and S. R. Sikdar. 2008. Production and characterization of somatic hybrids raised through protoplast fusion between edible mushroom strains Volvariella volvacea and Pleurotus florida. World J. Microbiol. Biotechnol. 24: 1481-1492.

Chatterjee, T., B. K. Chatterjee, D. Majumdar and P. Chakrabarti. 2015. Antibacterial effect of silver nanoparticles and the modeling of bacterial growth kinetics using a modified Gompertz model. Biochim. Biophys. Acta. 1850: 299-306.

Edwards, C. 1993. The significance of in situ activity on the efficiency of monitoring methods. In: Monitoring Genetically Microorganisms in the Environment, John Wiley and Sons, New York, pp. 1-25.

Eger, G., G. Eden and E. Wissig. 1976. Pleurotus ostreatus-breeding potential of a new cultivated mushroom. Theor. Appl. Genet. 47: 155-163.

Eichlerová, I. and L. Homolka. 1999. Preparation and crossing of basidiospore-derived monokaryons-a useful tool for obtaining 
laccase and other ligninolytic enzyme higher-producing dikaryotic strains of Pleurotus ostreatus. Antonie Van Leeuwenhoek. 75: 321-327.

Eichlerová, I., K. Ruel, L. Homolka, J. P. Joseleau and F. E. Nerud. 2000. Ligninolytic characteristics of Pleurotus ostreatus strain F6 and its monokaryotic protoplast derivative P19. Can. J. Microbiol. 46: 1153-1158.

Fekedulegn, D., M. P. M. Siúrtáin and J. J. Colbert. 1999. Parameter estimation of nonlinear models in forestry. Silv. Fenn. 33: 327-336.

Fultz, S. A. 1988. Fruiting at high temperature and its genetic control in the basidiomycete Flammulina velutipes. App. Environ. Microbiol. 54: 2460-2463.

Gaitán-Hernández, R., M. Esqueda, A. Gutiérrez, A. Sánchez, M. Beltrán-García and G. Mata. 2006. Bioconversion of agrowastes by Lentinula edodes: The high potential of viticulture residues. Appl. Microbiol. Biotechnol. 71: 432-439.

Gibson, A. M., N. Bratchell and T. A. Roberts. 1987. The effect of sodium chloride and temperature on the rate and extent of growth of Clostridium botulinum Type $A$ in pasteurized pork slurry. J. Appl. Bacteriol. 62, 479-490.

Gil, M. M., F. A. Miller, T. R. Brandao and C. L. Silva. 2011. On the use of the Gompertz model to predict microbial thermal inactivation under isothermal and non-isothermal conditions. Food Eng. Rev. 3: 17-25.

Guadarrama-Mendoza, P. C., G. V. del Toro, R. Ramírez-Carrillo, F. Robles-Martinez, J. Yáñez-Fernández, M. E. Garín-Aguilar and G. Bravo-Villa. 2014. Morphology and mycelial growth rate of Pleurotus spp. strains from the Mexican Mixtec region. Braz. J. Microbiol. 45: 861-872.

Guillén-Navarro, G. K., F. J. Márquez-Rocha and J.E. Sánchez-Vázquez. 1998. Producción de biomasa y enzimas ligninolíticas por Pleurotus ostreatus en cultivo sumergido. Rev. Iberoam. Mico. 15: 302-306.

Imbernon, M., C. Brian and S. Graniti. 1983. New strains of Pleurotus. Mushroom J. 124: 117-123.

Hills, B. P. and K. M. Wright. 1994. A new model for bacterial growth in heterogeneous systems. J. Theor. Biol. 168: 31-41.

Kashangura, C., J. E. Hallsworth and A. Y. Mswaka. 2006. Phenotypic diversity amongst strains of Pleurotus sajor-caju: Implications for cultivation in arid environments. Mycol. Res. 110: 312-317.

Kawasumi, T., N. Kiuchi, Y. Futatsugi, O. H. B. Kazuhiro and S. O. Yanagi. 1987. High yield preparation of Lentinus edodes ("Shiitake") protoplasts with regeneration capacity and mating type stability. Agric. Biol. Chem. 51: 1649-1656.

Leal-Lara, H. and G. Eger-Hummel. 1982. Amonokaryotization method its use for genetic studies in wood-rooting basidiomycetes. Theor. Appl. Genet. 61: 65-68.

Leatham, G. F. and M. A. Stahmann. 1987. Effect of light and aeration on fruiting of Lentinula edodes. Trans. Br. Mycol. Soc. 88: 9-20.

Liu, H., N. Chen, C. Feng, S. Tong and R. Li. 2017. Impact of electrostimulation on denitrifying bacterial growth and analysis of bacterial growth kinetics using a modified Gompertz model in a bio-electrochemical denitrification reactor. Bioresour. Technol. 232: 344-353.

López-Peña, D., A. Gutiérrez and M. Esqueda. 2013. Cinética de crecimiento y composición química del micelio de Lentinula edodes cultivado en medio líquido suplementado con extractos de madera de vid. Rev. Mex. Mic. 37: 51-59.

Mallik, P. and S. R. Sikdar. 2014. Production and molecular characterization of somatic hybrids between Pleurotus florida and Lentinula edodes. World J. Microbiol. Biotechnol.
30: 2283-2293.

Manzi, P., L. Gambelli, S. Marconi, V. Vivanti and L. Pizzoferrato. 1999. Nutrients in edible mushrooms: An inter-species comparative study. Food Chem. 65: 477-482.

Manzi, P., A. Aguzzi and L. Pizzoferrato. 2001. Nutritional value of mushrooms widely consumed in Italy. Food Chem. 73: 321-325.

Martínez-Carrera, D., P. Morales, M. Sobal, M. Bonilla, W. Martínez and Y. Mayett. 2012. Los hongos comestibles, funcionales y medicinales: Su contribución al desarrollo de las cadenas agroalimentarias y la seguridad alimentaria en México. In: Memorias Reunión General de la Academia Mexicana de Ciencias: Ciencia y Humanismo (Agrociencias). Academia Mexicana de Ciencias, México D.F, pp. 449-474.

McDonald, K. and D. W. Sun. 1999. Predictive food microbiology for the meat industry: A review. Int. J. Food Microbiol. 52: 1-27.

Miles, P. G. and J. R. Raper. 1956. Recovery of the component strains from dikaryotic mycelia. Mycologia. 48: 484-494.

Mori, K., S. Fukai and A. Zennyoji. 1974. Hybridization of shiitake (Lentinus edodes) between cultivated strains of Japan and wild strains grown in Taiwan and New Guinea. Mushroom. S. C. 9: 391-403.

Ramírez-Carrillo, R. and H. Leal-Lara. 2002. Symmetrical Recovery of Monokaryotic Components from Lentinula edodes using Dedikaryotization. In: Proceedings of the $4^{\text {th }}$ International Conference on Mushroom Biology and Mushroom Products, p. 141-149.

Ramírez-Carrillo, R. 2011. Mejoramiento Genético de Lentinula. Ph.D. Dissertation, Universidad Autónoma de México, México.

Ramírez-Carrillo, R., C. Marroquín-Corona and H. Leal-Lara. 2011. Strain Improvement of Edible Fungi with Pleurotus eryngii Neohaplonts. In: Proceedings of the $7^{\text {th }}$ International Conference on Mushroom Biology and Mushroom Products (ICMBMP7), pp. 62-70.

Reis, F. S., L. Barros, A. Martins and I. Ferreira. 2012. Chemical composition and nutritional value of the most widely appreciated cultivated mushrooms: An inter-species comparative study. Food Chem. Toxicol. 50: 191-197.

Regina, M. 2001. Cinética do Crescimento Miceliano de Lentinula edodes (Berk.) Pegler em Bagaço de Cana-de-açúcar e Serragem de Eucalipto. Master Dissertation, Universidade Estadual Paulista Júlio de Mesquita Filho, Brasil.

Royse, D. J. 2014. A Global Perspective on the High Five: Agaricus, Pleurotus, Lentinula, Auricularia and Flammulina. In: Proceedings of the $8^{\text {th }}$ International Conference on Mushroom Biology and Mushroom Products (ICMBMP8), p 1-6.

Sánchez-Hernández, A., G. V. Toro, H. Leal-Lara, M. E. Garín-Aguilar, R. Villanueva-Arce and R. Ramírez-Carrillo. 2014. Lentinula edodes dedikariotization and production of inter-generic hybrids. J. Chem. Biol. Phys. 4, 130.

Sharma, V. P., S. Kamal, R. C. Upadhyay, S. Kumar, S. K. Sanyal and M. Singh. 2015. Taxonomy, phylogeny, cultivation and biological activities of a Lentinus species from Andaman and Nicobar Islands (India). Emirates J. Food Agric. 27: 570-576.

Straatsma, G., J. P. Gerrits, T. M. Gerrits, H. J. op den Camp and L. J. van Griensven. 1991. Growth kinetics of Agaricus bisporus mycelium on solid substrate (mushroom compost). J. Gen. Microbiol. 137: 1471-1477.

Valencia del Toro, G. and H. Leal-Lara. 1999. Estudios de compatibilidad entre cepas de Pleurotus spp con cuerpos fructíferos de diversos colores. Rev. Mex. Mic. 15: 65-71.

Valencia del Toro, G. and H. Leal-Lara. 2002. Fruit Body Color in Pleurotus spp. Hybrid Strains Obtained by Matings of Compatible 
Neohaplonts. In: Proceedings of the $4^{\text {th }}$ International Conference on Mushroom Biology and Mushroom Products, p. 151-159.

Zengin, G., C. Sarikurkcu, A. Aktumsek, S. Uysal, R. Ceylan, F. Anwar and M. H. Solak. 2015. A comparative fatty acid compositional analysis of different wild species of mushrooms from Turkey. Emirates J. Food Agric. 27: 532-536. 